\title{
Articles
}

\section{Translation: Certain Posits and Praxis}

\section{RAVICHANDRA P. CHITTAMPALLI*}

If all act of writing involves a certain essentialist process, that of an encoding in a specific language, the act of translation is one that problematizes writing. All translations are negotiations, and as such the borders of translation as a paradigm are amorphous. Translation at once deconstructs the given of the assumed relationship between the writer and the work. Translation deals with the other. It is anthropological at the exploitative end and aesthetic at the romantic. It is transgression of the unchanging essence of the original. Each translation, therefore, is popularly conceived as a minimal release of a word, a historicizing of the ahistoric meaning. Translation is the meant of the meaning, and therefore at the point of emergence necessitates a further othering. Lawrence Venuti sums up the status of translation today in the following words (Venuti 1992:3):

"The hierarchy of cultural practices that ranks translation lowest is grounded on romantic expressive theory and projects a platonic metaphysics of the text, distinguishing between the authorized copy and the simulacrum that deviates from the author".

Translation in India is perhaps the result of a constant need to familiarize oneself with the canonical literature. It is doubtful how many could commonly access either Pali or Sanskritic texts. Yet again, translations from Sanskrit into other languages have existed commonly on palmyra for a long time. Such translations were necessarily outside the religious and the ritualistic needs of a society. One may therefore very well arrive at a conjecture that in India at least, translation was an activity which secularised the text, and helped establish distinct linguistic traditions in a regional context. Nonformal events like Kathakalakshepa have traditionally

\footnotetext{
* Ravichandra Chittampalli is Reader in Dept. of Studies in English, University of Mysore
}

Translation Today Volume (1) No (1) Mar. 2004 (c) CIIL 2004. 
resorted to translation as orature. What is being stressed at this point is the remarkable tentativeness of the act of translation. It is an intellectual process where discourses are set in flow. It is, therefore, almost always meaningless to ask the question: 'What is being translated?' For, the question assumes that there is not only a unitary text of frozen contour but that there is a tenacious physical relationship between the author and the text that is being translated. Such an assumption can hardly be tenable in the face of Derrida's categorical assertion:

"And the sign must be the unity of a heterogeneity, since the signified (sense or thing, noeme or reality) is not in itself a signifier, a trace... The formal essence of the signified is presence, and the privilege of its proximity to the logos as phone is the privilege of essence."

It is therefore that translators abrogate a demanded responsibility to be true to the original. After all translating the original is a notion that is fraught with problems. For Andrew Benjamin, the act of translation is to question the origin itself. Look at what he says:

"The origin as that which is put into question brings Psychoanalysis and translation into contact since both are marked by the inevitability and necessity within their originsincluding their own conception of the origin - of the process named within Psychoanalysis as 'Nachtra Glichkeit', a term which at this stage can be translated as 'deferred action', or 'action at a distance'.

Such notions of the "essence" and of the "origin" lead to either conceiving of writing as an act of representation (Presence as a "Supplement of a supplement"- Derrida J. 1994:298), or as what interpolates. However, in both instances, what is at stake is the notion of translation as a search for the precise match. It is possible to concur with such a departure from a conservative notion of precision in translation. One is at this juncture reminded of Octavio Paz's own belief that poetry is an act of divorcing a word from its historicity (Octavio Paz, Introduction, Selected Poems,). If the act of writing is an act of freeing a word from its texted associations, translating that word should then necessarily involve not merely 
identifying the word in a climate of synonymous resonance. There are in fact always, in most cases, synonymity. However, synonyms betray. So then, is translation a search for uniqueness? One answer rests perhaps in the question: why does one translate? The answers could be many. However it is also conceivable that a translator is born when (s)he embarks on a sanguinary search for that which allows complimentarity in life. It would perhaps be wise to involve Umberto Eco (1997:350-351) at this juncture:

"The solution for the future is more likely to be in a community of peoples with an increased ability to receive the spirit, to taste or savour the aroma of different dialects. Polyglot Europe will not be a continent where individuals converse fluently in all the other languages; in the best of cases, it could be a continent where differences of language are no longer a barrier to communication, where people can meet each other and speak together, each in her own tongue, understanding, as best they can, the speech of others".

Translation strives towards such an end, of the commonwealth. The business of a translator then could perhaps be to bring the genius of one language into the climate of the other. That would constitute a practice in which the translator would work to the full the resources of the target language. It does not merely involve a couple of dictionaries, a thesaurus and a book of grammar. Look at what a significant translator of our classical texts, T.R.S. Sharma says in a recent book of his (TRS Sharma 2000:113):

"You need to savour the sound and the semantic values of the words and to be in love with them. Surrendering to the text in this way means most of the time being literal- for the "spirit killeth and the letter giveth life". That is how you retextualize the original in the receiving language. To maximize the problematic of translation, you need that the language you translate from and the one you translate into are alien, and not cognate languages".

Sharma is here talking about the aesthetics that is involved in the act of translating literary texts. Even as he summons Baudrillard's notion of the simulacra to disinvest the faith in the notion of the "real" (loc. cit. p.118), he clearly prioritises the 
translator's right to freedom from the linguistic categories of the source language. Such freedom is not absolute. No translator really takes it to be so. It is a limited freedom which a musician or a dancer enjoys in the performance of a composition. Consider, for instance, the necessary freedom that a translator may have to involve while translating a poem from Kannada into English. The poem 'Mahamaye' by U.R.Ananthamurthy has a second stanza that runs to an uninterrupted 25 lines. In its English translation the stanza is increased by 2 lines, with two sentence breaks. The first constitutes four lines while the second, eleven lines. And yet, grammatically the first sentence of four lines remains a fragment, in spite of the effort to make the fragment semantically whole. The effort of the translator was to somehow capture the slow movement towards a crescendo that the stanza in Kannada attempts. Apart from the achieved movement in its musicality, the significance of the verbal dynamics may yield very little.

In another instance, in that of G.K.Ravindra Kumar's poem titled 'Sarapali', which is, descriptively, 'linked chain of strong metal', normally iron or steel, the translator has taken recourse to its metonymic meaning and has titled the translation as THE SEQUENCE. Thus what has a metaphoric significance in Kannada is translated into its metonymic state in English. In that act the translator has attempted to provide for his own prejudice as to the evocative possibilities in English of a word like 'chain' acting as a metaphor. Though alliteration in language may not be retained when translated, the loss would prove minimal when other poetic elements such as onomatopoeia, internal rhyming, etc either substitute or help recapture the movement of the lines in the original. This is an act of finding resources embedded in the target language which could provide, not so much escape routes, but approaches to the genius of the host.

No word exists in any language without its cultural resonance. Therefore, in the task of transferring those cultural inscriptions of a word into the target language lies the genius of a translator. It is precisely here that the exercise of freedom prefigures. Consider for instance the title Bhujangaiahna Dashavatharagalu, a novel by Srikrishna Alanahalli. The word dashavatara, literally 'ten incarnations' does not signify any sacred connotation in this 
context. The word dashavatharagalu is replete with irony. Again, if literally, dasha is ten, one would be hard put to account for ten aspects or events in the life of Bhujangaiah that figure as benchmarks. It is therefore at once imperative to slough any suggestion to ten in English where the number connotes nothing. Avataragalu can perhaps be translated as reincarnation. But the word in English hardly carries the ironic import it has in Kannada. Interestingly the English language is already familiar with the word avatar, and is today popularly used synonymously with unreal representations such as the mask. It is also meant as a masquerade. Thus it grows possible for the translator to title the translation as The Avatars of Bhujangaiah, bringing to the reader in English what it had brought to the reader in Kannada.

The one important function that is attempted by the translator here is to provide the necessary tool through his act for people to belong, not in a process of assimilation, but in the politically correct process of sympathizing.

\section{References:}

Benjamin, Andrew 1992 Translating Origins: Psychoanalysis and Philosophy in Lawrence Venuti: Rethinking Translation.

Derrida, Jacques 1994 Of Grammatology, Trans. Gayatri Chakravarty Spivak, Delhi: Motilal Banarsidas Publications Pvt. Ltd.

Eco, Umberto 1995,1997 The Search for the Perfect Language, Trans. James Fentren, London: Fontana Press.

Lawrence, Venuti (ed). 1992 "Introduction", Rethinking Translation: Discourse, Subjectivity, Ideology, Lawrence Venuti, London and New York: Routledge.

Sharma, T.R.S 2000 Toward an Alternative Discourse, Shimla: Indian Institute of Advanced Studies. 